UDC: 811.111'255.4:004.738.2 https://doi.org/10.22190/JTESAP1803535S

\title{
BUILDING BRIDGES BETWEEN CULTURES - AN EXPERIMENT WITH COLLABRATIVE ONLINE INTERNATIONAL LEARNING (COIL)
}

\author{
Aneta Stefanova $^{1}$, Aurora Gómez Jiménez \\ ${ }^{1}$ University of Economics, Varna, Bulgaria, ${ }^{2}$ Universidad Nacional de Costa Rica (UNA) \\ ${ }^{1}$ E-Mail: aurora.gomez.jimenez@una.cr \\ ${ }^{2}$ E-Mail: aneta_stefanova@ue-varna.bg
}

\begin{abstract}
In today's internationalized business world professionals are increasingly using technology to work across different cultures, locations, and time zones. Success in such multi-cultural environment depends largely on the team members' cultural awareness and competence that could ensure smooth interaction and efficient contributions of all persons involved. To prepare future professionals for such communication and work process, the authors of this paper designed and implemented a joint project between $4^{\text {th }}$ year students studying for a degree in International Economic Relations at the University of Economics in Varna, Bulgaria, and $1^{\text {st }}$ year students from the University of Costa Rica (UCR) from the Business Administration major. The paper describes the process of collaboration within the project teams, the outcomes and the lessons learned from this educational experiment.
\end{abstract}

Key words: intercultural communication, online collaboration, English language teaching, business etiquette

\section{INTRODUCTION}

Collaborative learning has been applied for a long time as a pedagogical approach, allowing students to learn in the process of communication. According to Gerlach, "Collaborative learning is based on the idea that learning is a naturally social act in which the participants talk among themselves. It is through the talk that learning occurs." (Gerlach, 1994). In the current information era and globalised world of business and education, this approach has evolved into a concept named COIL (collaborative online international learning).

Collaborative Online International Learning (COIL) is an emerging pedagogy which is aimed at providing university students with meaningful international experience. The collaboration is between peers from partner institutions in geographically distant locations, under the guidance of educators and/or expert facilitators to foster intercultural dialogue and the development of digital and critical literacies as well as team-building and foreign language skills.

\section{BACKGROUND}

Two intercultural projects in different areas have already been completed between two universities in Costa Rica - the National University (UNA) and the University of

Submitted June $9^{\text {th }}, 2018$, accepted for publication October $12^{\text {th }}, 2018$ 
Costa Rica (UCR) on the one hand and the University of Economics, Varna on the other. The tasks assigned within these shared projects were to establish an intercultural dialogue among students from very different geographical, linguistic, political and cultural backgrounds, resulting in producing different outcomes: setting up a sustainable tourism joint venture in one case and researching a culture that is new to both classes of students in the other. This online exchange was expected to facilitate the practice of collaboration skills, to enhance students' interest in cultural diversity, and to show the dynamics of this online learning experience and motivate higher education officials to include this modality of technology-based education in curricula within all disciplines as an internationalized pedagogic practice.

The outcomes of the first project have been described in a paper by the same authors ${ }^{1}$, while this paper dwells on the results of the second project implemented by students from the University of Costa Rica and the University of Economics in Varna, Bulgaria. This second project was carried out with different groups of students who were assigned with different tasks, but a similar methodology was used to establish team interactions through skype, WhatsApp and a dedicated Facebook group as the main platform of information exchange. The description of the project is stated in the following sections.

\section{PRoject RATionale}

This project was designed and launched with the purpose of allowing students to build new skills and competences by making them step out of their comfort zone and enter a computer-/cell-phone-mediated environment that was conductive to a different manner of learning. The main learning objective was to research and prepare a presentation of a foreign culture using a set of dimensions and characteristics. Apart from achieving the goals of the assignment, we also expected students to acquire new skills and experiences in the process of collaborating across continents and time zones. The project required students to work collaboratively using different communication devices in order to research a culture that is unknown to either sets of students and to produce a report, as well as a power-point presentation to deliver in class. The cultural brief had to include the main social, economic, geographic, artistic aspects of a foreign culture, including dos and don'ts in a business context, subcultures, language, role of women, dress code, food and dinning, religious practices and other cultural aspects of the chosen culture that a business person will need to aware of when moving to this foreign country for work.

\section{Project Stages}

\subsection{Project launch}

The two professors introduced the project to their respective students and explained the rationale and expected outcomes. The students from the two universities were divided into six teams. The number of members in each team varied because some students stopped attending the class or because at the beginning of the course, some students

$\overline{{ }^{1} \text { http://press.mu-varna.bg/ojs/index.php/conf/issue/view/212 }}$ 
started to interact individually through WhatsApp or Facebook messenger and they preferred to work with their new friends since they had already found channels of communication and established a meeting routine.

\subsection{First encounters}

Most of the Bulgarian students had had intercultural experiences before the project, be it during an Erasmus mobility or during a work-and-travel programme in the USA. However, a direct juxtaposition of cultural perceptions as was the case with the joint project allowed them to compare peer reactions and attitudes in different situations and sometimes also to realize how their own culture is perceived at the other end. With the launch of the project in the beginning of the semester the two teachers from the partnering universities started uploading some ice-breaking videos and pictures and posting comments in the Facebook group that was especially created for the purpose. While the Costa Rican students were actively 'liking' or commenting on some of the materials, the Bulgarian students did not make themselves heard or seen in any way. After discussing their initial reactions, we found out that the Bulgarian students were waiting for a specific assignment in relation to the project so that they could become active. They did not feel it was up to them to take the initiative and communicate freely in the closed group that was supposed to be the meeting place for the participants from both continents. After some encouragement in this direction, the Bulgarians also started commenting and 'liking' posts in the group. In an effort to explain this cultural difference, we resorted to Hofstede's dimensions of culture ${ }^{2}$ and found that the biggest difference between the two participating cultures was in the Power Distance Index that we believed could explain the differences in taking initiative or waiting for instructions from superiors:

\section{Bulgaria $\times$ Costa Rica $\times$}

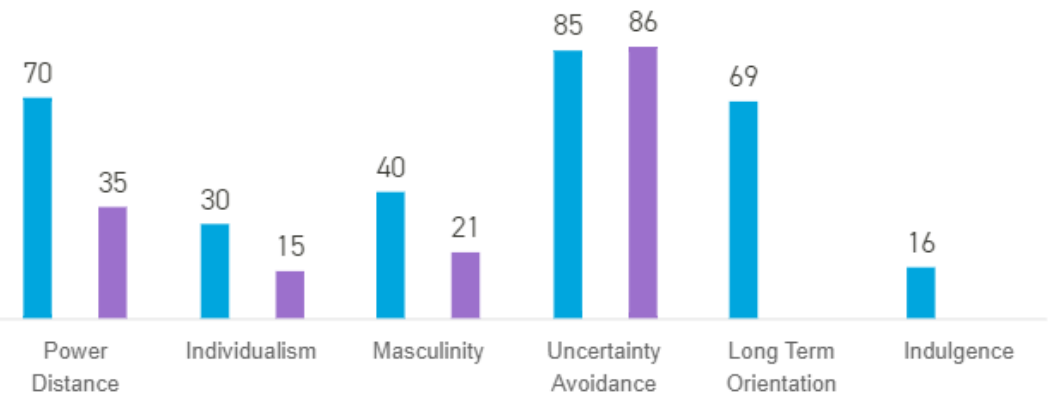

Fig. 1 Country comparison using the Hofstede model

Source: https://www.hofstede-insights.com/country-comparison/bulgaria,costa-rica/

${ }^{2}$ https://www.hofstede-insights.com/ 
With a score of 70 on the Power Distance Index, Bulgarians are among the countries in which people in less powerful positions expect to be told what to do and where the ideal boss is a benevolent autocrat. On the other hand, unlike most countries in Latin America, Costa Rica scores the lowest on this dimension in the region. To the surprise of many, especially in Latin America, where many countries have had military rule, Costa Rica is famous for its good human rights record. As Costa Ricans are very much focused on equality and consensus, there is less distance between people on different levels of hierarchy and therefore, in our case, students felt free to react and communicate without being afraid of making a grave mistake, unlike Bulgarian students who felt they should be officially assigned with a task before taking any action.

\subsection{Re-shaping the teams}

After the first introductions were made, there were complaints in one of the teams from one team member and demands followed with reshaping the teams. This was a delicate matter since on the one hand, there was no way of informing the student concerned that he was not a desired team member and on the other, we felt that because in real life situations one does not generally have the chance to choose who to work with, one rather has to adapt to the work situation. This incident was a valid demonstration of the need for intercultural competence in order for international teams to function smoothly. Young people are generally much more at ease when approaching their peers from different cultures, but the awareness that other people might have a different interpretation of what we say or do is crucial for building a relationship of trust and mutual understanding. In this particular case one of the female Costa Rican students felt uncomfortable because a male Bulgarian student from her team had asked her questions about her personal life. She took these questions as a threat to her privacy. After making the investigation to find out what had really happened, it was discovered that the Bulgarian student was only trying to be friendly and break the ice by asking about topics such as family and hobbies plus a very innocent comment saying to the girl that "she was pretty". After the misunderstanding was detected, the professor in Costa Rica explained to her class that men and women can interact differently in different cultures. She also suggested that if somebody feels uncomfortable with a word, topic or question asked by a team member, the best thing to do is to address it directly with the other person right away because probably the other person has not realized his/her comment or question was a sensitive one or maybe it was the student herself who misunderstood the intention of the comment based on previous experiences or stigmas. For example, each culture has topics that are taboos and people do not talk about them directly. These topics change from country to country. Finally, minor adjustments were made to the teams' composition so that morale was restored. 


\subsection{The actual online collaboration work}

After the teams were finally formed, each team had to choose a culture they wanted to research. The six teams chose the following countries to focus on: Germany, Brazil, Italy, Canada, Russia, and Dominican Republic. The students were required to have virtual meetings and video conference calls to get all the material together and organize an interview with a representative of the target culture.

During the first stages of the project, the students were mainly guided by the professors who helped them establish a closer contact through background information about each country and the possible differences they could find between the two cultures. The students themselves exchanged videos and information about their respective countries, cities and universities. After this familiarization stage the students were more independent to set their own rules of work. The only condition that they had to consider was the need to carry out a minimum of two skype calls involving all team members. Each group had to report to their professor: the date, time, and length, main point of discussions, outcomes and assignments agreed during each virtual meeting.

For the students in Costa Rica, using Skype was a new experience because they had never worked in an international team before. At the beginning, there were a lot of questions on how to carry out a meeting with people at the other side of the world and be productive. The first meetings were concise and very organized to discuss the main points of research to be able to accomplish the task together. The average duration of these first meetings was 20-25 minutes. The second meetings were more open to discussion on the main sections of the report that the teams had to produce on the respective culture, as well as outlining the questions they wanted to ask for the final interview. These second meetings lasted longer than the first ones: an average of 30-40 minutes each.

An interesting fact was the way students managed to participate in the final presentation of their partners even though they were all far away from each other. For doing this, all the members of the group collaborated in making a power point presentation which included all the sections of the report. The students from the fellow university recorded the explanation of their section and it was played during the final presentation so the audience had the impression that their fellow students were also active during the final live presentation. There was a group that even managed to do a Skype video call; despite the time difference, one student from Bulgaria presented his section of the report during this Skype call. The groups also presented videos and recordings made with expatriates coming from their target culture and analyzed their experiences and perceptions about their own and the host culture and how their adaptation and understanding of the new culture was essential to perform well in their social, professional and personal life. This interview sample can be found at https://www.youtube.com/watch?v=WO7CSQ-tqVw\&t=104s

During the final presentations the students shared their perceptions about the target culture and identified similarities and differences with their own culture. Hofstede's Cultural Dimensions were directly experienced by the students during their team work and research on a target culture because they had to explain from the target culture's point of view their way of seeing the world and how these perceptions can be better understood in their native culture. 


\section{THE OUTCOMES}

The COIL assignment brought points to the overall score of the students in their respective courses. And while students from the two universities did the project as part of their English-language instruction, apart from the enhancement of their language competences, the collaborative learning assignment brought about other consequences that we believe could be of great use to students in their future personal and professional development:

- Building social and interpersonal skills. We believe that the effects of efficient and successful collaboration on students' self-esteem and personal development are just as important as the learning itself.

- Enhancing problem-solving and critical thinking skills. In our view, students with problem-solving and critical thinking skills will perform best in today's economy. The said skills, along with effective communication and teamwork, are among the abilities most sought-after by employers. In this project students had to research an abundant amount of information and to sieve through various viewpoints in order to define the parameters of a culture they are not familiar with. They had to compare their findings and conclusions with the testimonials of a member of the respective culture and maybe revise their work after the interview.

- Developing distance work abilities. Today's ever-expanding virtual workplaces are changing the way people do their jobs, communicate, form work relationships, and get results. Smaller, cheaper, more accessible technology tools have enabled a dynamic mobile workplace where people connect from wherever they are. An increasing number of people work away from the office on a regular or permanent basis. Such virtual or distance jobs require people to work together when they are not actually together. One of the major setbacks in the project work was timing of the interaction between the team members and the time management that the 9-hour time difference required. After a couple of weeks, during which both sets of students were trying to work out how the collaboration would work given the big time difference, they found the time interval that allowed live interaction between the team members - in most cases, the late evening hours in Europe and early morning in Central America.

\section{The STUdents’' PeRsPeCtive}

While students showed mild opposition against this assignment initially, in the process of carrying it out they gained confidence and grew to like the challenge they were confronted with, which is evident from the feedback they gave in the end. As a general pattern, the students percieved a stronger connection with countries which are located in their same continent; with the exception of Germany that none of the teams felt similar with. 
The feedback students gave in the beginning and at the end of the project was positive. They shared that they had not expected such an approach to learning English but that they were pleased to be faced with such a challenge that was conductive to meeting people from a different continent and culture and becoming aware of cultural differences and ways of their overcoming so that the teamwork is carried out successfully.

"To begin with, I find the intercultural project very challenging and interesting. I think we have a lot of experience and knowledge to share. The students seem very open to us and friendly. Working together would be hard because of the big time difference and everybody's busy schedules, but I'm full of hope that we'll manage to get things done and as a result to present some good projects." Sophia, Bulgaria

"This project is something new to me. In the beginning I thought that we're going to have a lot of communication problems, because of the distance and the time difference, but at the moment me and my group have found acceptable ways to communicate and work together. "Nedelina, Bulgaria

"I am very pleased that we work together on this project, because me make progress really fast and we also gain valuable and pleasant experience." Yonka, Bulgaria

Table 1 Teams' Output

\begin{tabular}{|c|c|c|c|c|c|}
\hline Team No. & $\begin{array}{l}\text { No. of } \\
\text { team } \\
\text { members }\end{array}$ & $\begin{array}{l}\text { No. of } \\
\text { Costa Rican } \\
\text { students } \\
\end{array}$ & $\begin{array}{l}\text { No. of } \\
\text { Bulgarian } \\
\text { Students } \\
\end{array}$ & $\begin{array}{l}\text { Target } \\
\text { culture }\end{array}$ & $\begin{array}{l}\text { Students' observations } \\
\text { about } \\
\text { cultural distance }\end{array}$ \\
\hline 1 & 3 & 2 & 1 & $\begin{array}{l}\text { Dominican } \\
\text { Republic }\end{array}$ & $\begin{array}{l}\text { Closer to Costa Rican } \\
\text { culture } \\
\text { Farther from Bulgarian } \\
\text { culture }\end{array}$ \\
\hline 2 & 6 & 2 & 4 & Brazil & $\begin{array}{l}\text { Closer to Costa Rican } \\
\text { culture } \\
\text { Farther from Bulgarian } \\
\text { culture }\end{array}$ \\
\hline 3 & 7 & 3 & 4 & Italy & $\begin{array}{l}\text { Farther from Costa Rican } \\
\text { culture } \\
\text { Closer to Bulgarian } \\
\text { culture }\end{array}$ \\
\hline 4 & 3 & 2 & 1 & Canada & $\begin{array}{l}\text { Closer to Costa Rican } \\
\text { culture } \\
\text { Farther from Bulgarian } \\
\text { culture }\end{array}$ \\
\hline 5 & 4 & 1 & 3 & Russia & $\begin{array}{l}\text { Farther from Costa Rican } \\
\text { culture } \\
\text { Closer to Bulgarian } \\
\text { culture }\end{array}$ \\
\hline 6 & 3 & 2 & 1 & Germany & $\begin{array}{l}\text { Farther from Costa Rican } \\
\text { culture } \\
\text { Farther from Bulgarian } \\
\text { culture }\end{array}$ \\
\hline
\end{tabular}

Source: Authors' project summary 


\section{CONCLUSION}

As students share ideas and collaborate with peers from a far-away location, they achieve a wider global perspectives and broaden their understanding of global topics that extend beyond their home and host countries. Within a structured academic environment, students develop valued professional skills as they work together on international projects with students from another university. The COIL model allows them to learn how to effectively communicate across time zones, national boundaries, and interpersonal barriers. Students also learn important group collaboration skills and develop powerful strategic thinking skills.

By discovering other cultures through research work or hands-on experience students become aware of their own culture and sometimes this comes as a revelation to them. Awareness of one's own culture is important, because it can keep us from projecting our values onto others. This can happen when we are unaware of the values that drive us and are unable to distinguish them from those held by other cultures. Such intercultural projects give students the ability to compare their ways and values with the ways and values of other people that they have to get work done with.

This project was a very enriching experience for students from both universities. Even though they had had contact with people form a different cultural background before, it was the first time they had both worked in an international team through social media with people from Latin America and Europe, respectively. They had to make adjustments of style regarding their way of organizing time, research, preparing reports and assignments. It was a difficult adjustment at the beginning because of the time difference and taking decisions on content and analysis of data, but at the end of the project students were all very proud of the outcomes and learned not only about their target culture but also about their own culture when they had to face questions and process information to find similarities and differences in ways to do business and carry out everyday activities in different parts of the world.

\section{REFERENCES}

Herrington, T. (2004). Where in the world is the Global Classroom Project? In J. Di Leo \& W. Jacobs (Eds.), If classrooms matter: Progressive visions of educational environments (pp. 197-210). New York: Routledge.

Gerlach, J. M. (1994). "Is this collaboration?" In Bosworth, K. and Hamilton, S. J. (Eds.), Collaborative Learning: Underlying Processes and Effective Techniques, New Directions for Teaching and Learning No. 59.

Hofstede, G. https://www.hofstede-insights.com/ 